\title{
Selection of Maize Genotypes Resistant to Pink Stem
}

\section{Borer and Sugarcane Borer}

\author{
Abraham Agwu Ngwuta ${ }^{1}$, Samson Oyewole Ajala ${ }^{2}$, Ignatius Ugwudike Obi ${ }^{3}$ and Ene-Obong Efiom Ene-Obong ${ }^{4}$ \\ 1. Department of Crop Science and Technology, School of Agriculture and Agricultural Technology, Federal University of \\ Technology, Owerri 460001, Nigeria \\ 2. Maize Improvement Programme, International Institute of Tropical Agriculture, Ibadan 200001, Nigeria \\ 3. Department of Crop Science, Faculty of Agriculture, University of Nigeria, Nsukka 400001, Nigeria \\ 4. Department of Crop Science, Faculty of Agriculture, Cross River State University of Technology, Calabar 540001, Nigeria
}

\begin{abstract}
Maize is an important economic crop grown in Nigeria. Its production is dramatically affect by the pink stem borer-Sesamia calamistis (Hampson, Noctuidae) and sugarcane borer-Eldana saccharina (Walker, Pyralidae) that are endemic in Southeastern Nigeria. In areas of stress, existing genotypes may marginally do well due to their inherent capabilities. Therefore, it is possible to find useful genes in such areas of stress, since such genes have been responsible for the survival of host crops over the years. Evaluation study was conducted for a range of agronomic characteristics and resistance attributes for 209 local maize collections from Southeastern Nigeria along with three improved check varieties. Field trials were conducted at three locations in a total of four environments in 2001. Highly significant genotypic variances as were noted in all the traits, are indicative of the magnitude of variation that exists among the genotypes, thus providing the opportunity of selection for desirable traits. Furthermore, four traits, namely, leaf feeding, ear damage, stalk lodging and yield were used from across the environments to construct a rank summation index (RSI), which was used to rank the entries for resistance to stem borers. This RSI led to the identification of 11

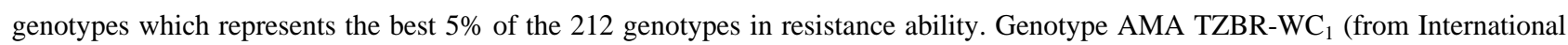
Institute of Tropical Agriculture (IITA), Ibadan) had the best overall resistance levels, followed by genotypes SE NG-77 and SE NG-67 (from Umuahia North), SE NG-62 (from Ikwuano), SE NG-148 (from Ukwa West), SE NG-106 (from Bende), SE NG-119 (from Isiala Ngwa), SE NG-33 (from Ikwuano) and SE NG-65 (from Umuahia North).
\end{abstract}

Key words: Zea mays, Sesamia calamistis, Eldana saccharina, genetic variance, rank selection index, stem borer resistance.

\section{Introduction}

Maize is a traditional crop generally grown for a variety of food products and consumption in Southeastern Nigeria, but it is not native to the zone, which implies that all the varieties grown were introduced and maintained by the farmers over the years. Southeastern Nigeria is a rain forest zone characterized by a long duration rainfall-April to November, low insolation and high relative humidity with a very high prevalence of disease and insect pressure. Severe biotic challenges, including foliar

Corresponding author: Abraham Agwu Ngwuta, Ph.D., research fields: crop improvement, development of stem borer resistant maize varieties. E-mail: angwuta@gmail.com. diseases, stem borer attacks, stalk and ear damages, are some of the major factors that reduce maize yields drastically. Several workers have reported stem borers as one of the most serious constraints to maize production in West and Central Africa [1-11]. In Africa, yield loss ranging from $10 \%$ to $100 \%$ has also been recorded in maize because of the attack of stem borer [12]. Both the pink stem borer (Sesamia calamistis (Hmpson)) and the sugarcane stem borer (Eldana saccharina (Walker)) are of economic importance in Southeastern Nigeria [13-15].

Maize is a cross pollinated crop, and due to the traditional practice of local farmers to save some harvest as seeds for next crop sowing, inter-crossing in farmers' fields over the years could have changed 
the genetic constitution of varieties being grown. More often than not, farmers' selections of seeds for the next crop represent a form of mass selection for yield and tolerance to biotic and abiotic stresses [16-20]. This study aimed to determine the usefulness of maize germplasm grown in Southeastern Nigeria as potential sources of useful genes for maize improvement [20, 21]. The objectives of the study were to evaluate the maize genotypes grown in Southeastern Nigeria for agronomic traits and the response to stem borer damage to select the best performing genotypes for further maize improvement programme.

\section{Materials and Methods}

Two hundred and twelve maize genotypes were used in this study. These genotypes comprised of 209 local open-pollinated cultivars and three advanced genotypes from International Institute of Tropical Agriculture (IITA), Ibadan, Nigeria. The advanced genotypes were used as checks. Samples of local maize cultivars were collected by students of Michael Okpara University of Agriculture, Umudike, Abia State, who normally reside in maize producing local government areas of Southeastern Nigeria. The collected samples were at least $1 \mathrm{~kg}$ per sample from their respective locations. The collection site, site codes and genotype names of the germplasm are explained in Table 1 . The genotypes were numbered according to the locations from where they were collected, and codes were assigned as A to $\mathrm{Z}$ and AA to $\mathrm{AI}$ for ease of identification. Genotypes 1 to 209 were collected from the various locations in Southeastern Nigeria, while genotypes 210 (TZBR-W-1), 211 (AMA TZBR-WC $_{1}$ ) and 212 (TZBR Eld $\mathrm{C}_{2}$ ), which were at their advanced stages of improvement, were collected from IITA, Ibadan, Nigeria. Genotype 209 from Ikwuano was collected after the serial numbering of the genotypes, thus explaining the gap between the last two genotypes from that location. The highest number of genotypes
(65) was collected from Ikwuano, followed by Umuahia North (21), Bende (16) and Umuahia South (15) all from Abia state. Other locations however contributed one to seven genotypes.

The 212 genotypes comprising the 209 from Southeastern Nigeria were numbered as SE NG-1 to SE NG-209 (SE NG = Southeastern Nigeria). The three improved genotypes from IITA, Ibadan, along with the 209 genotypes were evaluated during the planting seasons of 2001 in four environments. One of the environments was represented under artificial infestation with egg masses of S. calamistis at Ibadan. The other three environments includes: Egbema-a stem borer endemic location in Southeastern Nigeria, a non-infested trial at Ibadan and another one at Ikenne. The trials at Ibadan were established on May 22, 2001, while those of Ikenne and Egbema were planted on May 25 and 29, 2001, respectively. Both Ibadan and Ikenne are located in the Southwest of Nigeria and are separated by a distance of $80 \mathrm{~km}$. Egbema on the other hand is in Imo State and is approximately $800 \mathrm{~km}$ South of Ibadan.

The experiments were laid out in a randomized complete block design (RCBD) with two replications. Trials were planted at Egbema and Ikenne with a row length of $5 \mathrm{~m}$ and the interrow spacing of $0.75 \mathrm{~m}$.

In Ibadan, row length was kept as $6.5 \mathrm{~m}$ with each row sub divided into two equal halves of $3 \mathrm{~m}$ with a space of $0.5 \mathrm{~m}$ in the middle. One half of the plot was artificially infested with egg mass of S. calamistis, while the other half constituted the non-infested plot. Interrow spacing was kept same throughout all the trials as $0.75 \mathrm{~m}$. In all the plots, two seeds were planted at an intra-row spacing of $0.25 \mathrm{~m}$. Thinning was done at three weeks after planting (WAP), leaving one plant per stand to give a population density of 53,333 plants/ha.

Fertilizer was applied in two splits in each trial. A basal application with $60 \mathrm{~kg}$ of $\mathrm{N}, 60 \mathrm{~kg}$ of $\mathrm{P}_{2} \mathrm{O}_{5}$ and $60 \mathrm{~kg}$ of $\mathrm{K}_{2} \mathrm{O}$ was given immediately after thinning. The second application was made with $30 \mathrm{~kg}$ of N/ha. 
Table 1 Codes, collection sites and accession numbers for the local open-pollinated and improved maize genotypes evaluated as potential sources of resistance to $S$. calamistis and E. saccharina.

\begin{tabular}{|c|c|c|c|c|c|c|c|c|c|c|c|c|c|c|c|c|c|c|}
\hline Code & $\begin{array}{l}\text { Collection } \\
\text { sites }\end{array}$ & Entry & $\mathrm{s}$ of $\mathrm{m}$ & types & & & & & & & & & & & & & & $\begin{array}{l}\text { Number of } \\
\text { genotypes per }\end{array}$ \\
\hline \multirow{5}{*}{ A } & \multirow{5}{*}{ Ikwuano } & 1 & 2 & 3 & 4 & 5 & 6 & 7 & 8 & 9 & 10 & 11 & 12 & 13 & 14 & 15 & 16 & \multirow{5}{*}{65} \\
\hline & & 17 & 18 & 19 & 20 & 21 & 22 & 23 & 24 & 25 & 26 & 27 & 28 & 29 & 30 & 31 & 32 & \\
\hline & & 33 & 34 & 35 & 36 & 37 & 38 & 39 & 40 & 41 & 42 & 43 & 44 & 45 & 46 & 47 & 48 & \\
\hline & & 49 & 50 & 51 & 52 & 53 & 54 & 55 & 56 & 57 & 58 & 59 & 60 & 61 & 62 & 63 & 64 & \\
\hline & & 209 & & & & & & & & & & & & & & & & \\
\hline B & $\begin{array}{l}\text { Umuahia } \\
\text { North }\end{array}$ & 81 & 82 & 83 & 84 & 85 & & & & & & & & & & & & 21 \\
\hline C & $\begin{array}{l}\text { Umuahia } \\
\text { South }\end{array}$ & 86 & 87 & 88 & 89 & 90 & 91 & 92 & 93 & 94 & 95 & 96 & 97 & 98 & 99 & 100 & & 15 \\
\hline D & Uzuakoli & 101 & & & & & & & & & & & & & & & & 1 \\
\hline E & Bende & 102 & 103 & 104 & 105 & 106 & 107 & 108 & 109 & 110 & 111 & 112 & 113 & 114 & 115 & 116 & 117 & 16 \\
\hline $\mathrm{F}$ & Isiala Ngwa & 118 & 119 & 120 & 121 & 122 & 123 & & & & & & & & & & & 6 \\
\hline G & Ohafia & 124 & 125 & 126 & 127 & 128 & & & & & & & & & & & & 5 \\
\hline I & Aba south & 130 & 131 & & & & & & & & & & & & & & & 2 \\
\hline $\mathrm{J}$ & Osisioma & 132 & 133 & 134 & & & & & & & & & & & & & & 3 \\
\hline K & Arochukwu & 135 & 136 & 137 & 138 & 139 & & & & & & & & & & & & 5 \\
\hline $\mathrm{L}$ & Isuikwuato & 140 & 141 & 142 & 143 & & & & & & & & & & & & & 4 \\
\hline M & Nnochi & 144 & & & & & & & & & & & & & & & & 1 \\
\hline N & Ukwa West & 145 & 146 & 147 & 148 & & & & & & & & & & & & & 4 \\
\hline $\mathrm{O}$ & Owerri North & 149 & 150 & 151 & 152 & & & & & & & & & & & & & 4 \\
\hline $\mathrm{P}$ & Obowo & 153 & 154 & 155 & & & & & & & & & & & & & & 3 \\
\hline Q & Aboh Mbaise & 156 & 157 & 158 & 159 & 160 & 161 & 162 & & & & & & & & & & 7 \\
\hline $\mathrm{R}$ & Ehime Mbano & 163 & 164 & 165 & 166 & 167 & & & & & & & & & & & & 5 \\
\hline S & Ihite Uboma & 168 & & & & & & & & & & & & & & & & 1 \\
\hline $\mathrm{T}$ & Egbu & 169 & & & & & & & & & & & & & & & & 1 \\
\hline U & Ahiazu & 170 & 171 & 172 & 173 & 174 & 175 & & & & & & & & & & & 6 \\
\hline V & Mbaitoli & 176 & 177 & 178 & 179 & 180 & & & & & & & & & & & & 5 \\
\hline
\end{tabular}


(Table 1 continued)

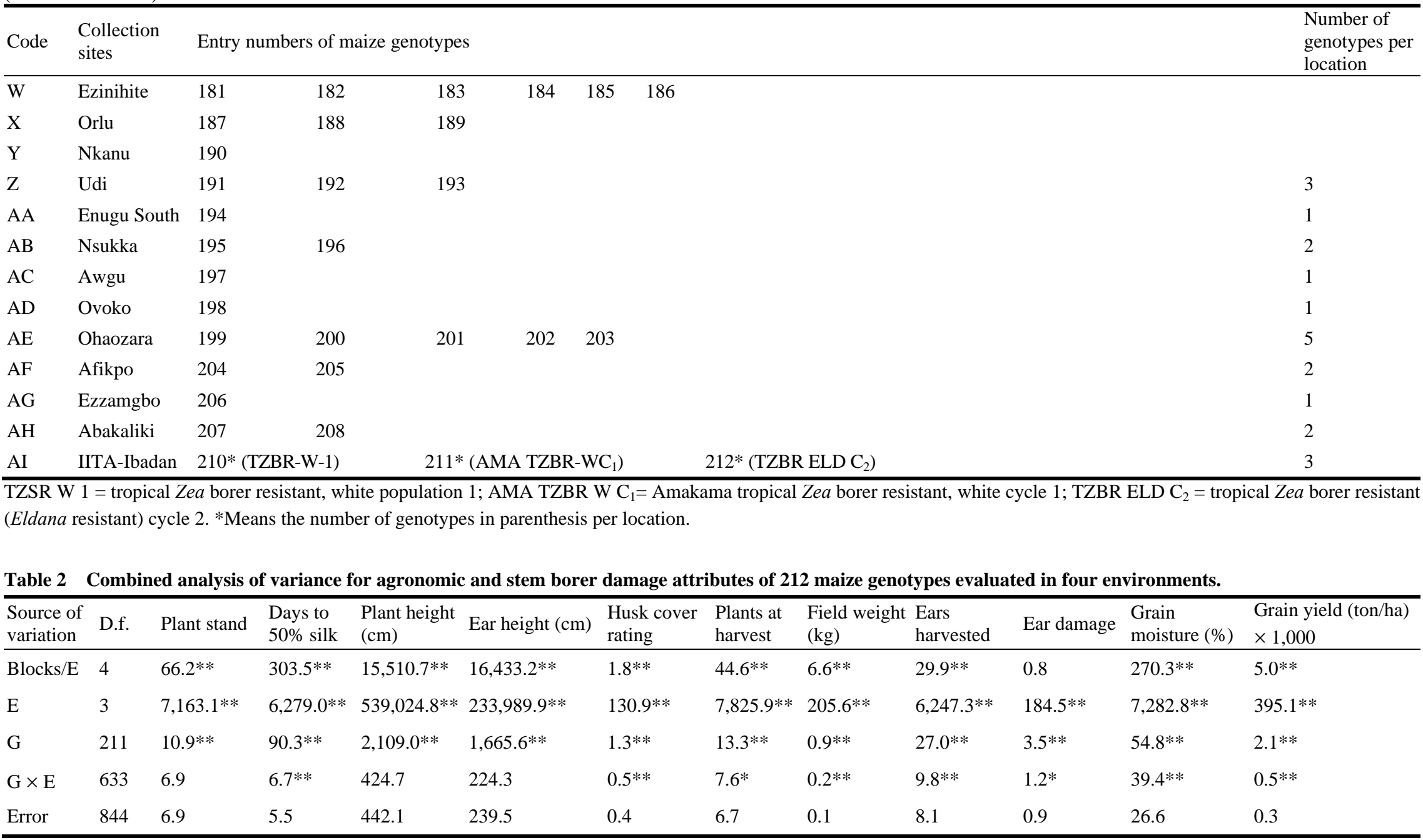

$\mathrm{E}=$ environment; G: genotype; *, ** = significant at $P=0.05$ and $P=0.01$, respectively; D.f. $=$ degree of freedom; blocks/E $=$ blocks within environments. 
Weeds were controlled with a pre-emergence application of Primextra herbicide (4 L/ha). Further weed control on the plots was done manually by hand hoes at 6 WAP and 9 WAP. At 11 WAP, Gramoxone alone was applied to ensure weed control at crop maturity stage. All genotypes of the infested trial at Ibadan were artificially infested with egg masses of $S$. calamistis containing about 40 eggs at the black head stage and introduced into the leaf sheath at three weeks after emergence (WAE).

\subsection{Data Collection}

The data was collected at all the three locations for plant stand, days to $50 \%$ silking, plant height, plant aspect, ear aspect, husk cover rating, plants at harvest, ears harvested, grain moisture, field weight and grain yield. Data on stem borer damage was collected at Ibadan and Egbema for the artificially and naturally infested trials, respectively for leaf feeding, dead heart, stem tunneling, ear damage, root lodging and stalk lodging.

\subsection{Statistical Analysis}

Analysis of variance (ANOVA) was computed separately for the genotypes in each location and then combined across environments. Subsequently, a restricted maximum likelihood (REML) procedure [22] was used for the agronomic traits and stem borer damage parameters. The statistical model for the combined ANOVA is given as Eq. (1):

$$
Y_{i j k}=R_{j}+G_{k}+G E_{i k}+e_{i j k}
$$

where,

$$
\begin{aligned}
& i=1,2,3,4 \text { (environments); } \\
& j=1,2 \text { (replications); } \\
& k=1,2,3 \ldots 212 \text { (genotypes); } \\
& E_{i}=\text { the effect of environment } i \\
& G_{k}=\text { the effect of genotype } k ; \\
& G E_{i k}=\text { the interaction effect between genotype } k
\end{aligned}
$$
and environment $i$;

$e_{i j k}=$ error (residual).

Data which were obtained as percentages were transformed with the square root transformation procedure as described by Obi [23] before performing the ANOVA. The environments and genotypes were considered randomly in determining the expected mean squares for the analysis.

\subsection{Estimation of Genetic Variance Components}

Using the expected mean squares for ANOVA, the variance components were calculated as the method suggested by Hallauer and Miranda [24], while broad sense heritability estimates were obtained as the proportion of the total variation (phenotypic) that is due to genetic effect and calculated as Eq. (2):

$$
B S H\left(h^{2}\right)=\frac{\sigma_{G}^{2}}{\sigma_{p h}^{2}}=\frac{\sigma_{G}^{2}}{\sigma_{G}^{2}+\sigma_{E}^{2}}
$$

where, $B S H\left(h^{2}\right)=$ broad sense heritability, $\sigma_{G}^{2}=$ genetic variance, $\sigma_{p h}^{2}=$ total or phenotypic variance and $\sigma_{E}^{2}=$ environmental variance.

A rank summation index (RSI) method [25] was then used to rank the genotypes for their overall performance with respect to damage caused by borers and agronomic characteristics across all environments. To obtain the RSI, genotypes were first ranked for each parameter (in this case, $1=$ best and $212=$ poorest) and parameter ranks were summed to generate overall performance of each genotype. Thus, the lower the value of RSI of any genotype is, the greater is its resistance and the better is its agronomic performance.

\section{Results and Discussion}

Highly significant $(P=0.01)$ differences were obtained in almost all cases for all the traits for both environments and genotypes. Furthermore, genotype-by-environment $(G \times E)$ interaction effects were significant for all traits, except for plant stand, leaf feeding and plant and ear heights (Tables 2 and 3). Genotypic variance estimates for the traits were generally less than the environmental variances except for plant and ear aspects (Table 4). Generally, genotypes 
Table 3 Combined analysis of variance for agronomic and stem borer damage parameters of 212 maize genotypes evaluated in two environments.

\begin{tabular}{lllllll}
\hline Source of variation & Degrees of freedom & Leaf feeding & Plant aspect & Root lodging & Stalk lodging & Ear aspect \\
\hline Blocks/E & 2 & 1.4 & $3.6^{* *}$ & 7.4 & 7.5 & 0.2 \\
E & 1 & $221.1^{* *}$ & $10.9^{* *}$ & $213.0^{* *}$ & $1,042.0^{* *}$ & $0.3^{* *}$ \\
$\mathrm{G}$ & 211 & $0.7^{* *}$ & $2.1^{* *}$ & $6.0^{* *}$ & $14.5^{* *}$ & $2.1^{* *}$ \\
$\mathrm{G} \times \mathrm{E}$ & 211 & 0.7 & $0.9^{* *}$ & $4.8^{* *}$ & $10.7^{* *}$ & $0.8^{* *}$ \\
Error & 422 & 0.6 & 0.8 & 3.5 & 7.3 & 0.6 \\
\hline
\end{tabular}

E: environment; G: genotype; blocks/E = blocks within environments; *, ** = significant at $P=0.05$ and $P=0.01$, respectively.

Table 4 Variance components and heritability (broad sense) estimates of some agronomic and stem borer damage parameters of the 212 maize genotypes.

\begin{tabular}{lllllll}
\hline Source of variation & $\sigma_{G}{ }_{G}$ & $\sigma_{E}^{2}$ & $\sigma_{G \times E}^{2}$ & $\sigma_{e}^{2}$ & $\sigma_{P h}^{2}$ & $B S H\left(h^{2}\right)(\%)$ \\
\hline Plant stand & 0.48 & 16.87 & 0.00 & 7.00 & 17.35 & 2.77 \\
Days to 50\% silking & 10.44 & 14.19 & 0.60 & 5.50 & 25.23 & 41.38 \\
Leaf feeding & 0.01 & 0.52 & 0.06 & 0.60 & 0.59 & 1.69 \\
Plant height (cm) & 204.20 & $1,270.00$ & 0.00 & 42.10 & $1,474.20$ & 13.85 \\
Ear height (cm) & 173.60 & 551.20 & 0.00 & 239.50 & 724.80 & 23.95 \\
Plant aspect & 9.31 & 0.02 & 0.01 & 3.50 & 9.34 & 99.68 \\
Root lodging (\%) & 0.28 & 0.49 & 0.65 & 7.30 & 1.42 & 19.72 \\
Stalk lodging (\%) & 1.08 & 2.43 & 1.47 & 0.50 & 4.98 & 21.69 \\
Husk cover rating & 0.10 & 0.31 & 0.06 & 0.40 & 0.47 & 21.28 \\
Plants at harvest & 0.71 & 18.44 & 0.35 & 6.80 & 19.50 & 3.64 \\
Field weight (kg) & 0.09 & 0.48 & 0.02 & 0.10 & 0.59 & 15.25 \\
Ears harvested & 2.15 & 14.71 & 0.84 & 8.10 & 17.70 & 12.15 \\
Ear aspect & 0.31 & 0.00 & 0.11 & 0.80 & 0.42 & 73.81 \\
Ear damage & 0.3 & 0.43 & 0.07 & 0.90 & 0.83 & 36.14 \\
Moisture (\%) & 1.92 & 17.08 & 5.79 & 26.70 & 24.79 & 7.75 \\
Grain yield (t/ha) & 0.03 & 0.93 & 0.06 & 20.30 & 1.02 & 2.94 \\
\hline
\end{tabular}

$\overline{\sigma_{G}^{2}}=$ genetic variance; $\sigma_{E}^{2}=$ environmental variance (within families); $\sigma_{G \times E}^{2}=$ genetic by environment interaction variance; $\sigma^{2}=$ experimental error; $\sigma_{p h}^{2}=$ total (phenotypic) variance and $B S H\left(h^{2}\right)=$ broad sense heritability.

by environment variance $(\mathrm{G} \times \mathrm{E})$ estimates were the lowest and negligible in some cases, but the estimates were relatively high for stalk lodging and grain moisture percent with values of 1.47 and 5.79, respectively. Broad sense heritability estimates for plant and ear aspects were high with values $>60 \%$ in each case, while days to $50 \%$ silking and ear damage rating had moderate $35 \%$ to $59 \%$ estimates. Heritability estimates for other traits were low with values less than $25 \%$.

Overall means for agronomic and borer damage characteristics of the genotypes evaluated in different environments (Table 5) show that in general, the proportion of plants per plot that suffered dead heart was low (2.0\%). Leaf feeding rating was also low with an average value of 3.0 and a range of 2-4, while average ear damage obtained for the genotypes ranged between 2.4 and 4.8 with average of 4.2. These show that some of the genotypes, which have low levels of borer damage ratings across the different environment, contain factors responsible for resisting borer attacks. On the average, genotypes attained 50\% silking in 63 $d$ with a range of 55-74 d, indicating that the maize genotypes grown in Southeastern Nigeria are mainly late maturing. Average height of the genotypes was $202.3 \mathrm{~cm}$, ranging from $146.2 \mathrm{~cm}$ to $253.9 \mathrm{~cm}$. Range of plant aspect rating was 2.5 to 6.5 , resulting in a moderate average rating of 4.8. Percentage of plants which lodged at the root (root lodging) was low (1.9\%), showing that many genotypes posses the ability 
Table 5 Primary data on the evaluation of 212 maize genotypes in two to four environments.

\begin{tabular}{lllllll}
\hline Plant trait & Mean & Minimum & Maximum & Range & CV (\%) & LSD $_{(0.05)}$ \\
\hline Dead heart (\%) & 2.04 & 0.00 & 6.50 & 6.50 & 80.00 & 3.30 \\
Leaf feeding & 2.81 & 2.00 & 4.50 & 2.50 & 26.30 & 1.00 \\
Ear damage & 4.20 & 2.40 & 4.80 & 2.40 & 22.80 & 1.00 \\
Plant stand & 14.82 & 10.75 & 17.00 & 6.25 & 17.90 & 5.30 \\
$50 \%$ silking (d) & 62.51 & 55.38 & 73.75 & 18.38 & 3.80 & 5.10 \\
Plant height (cm) & 202.32 & 146.15 & 253.90 & 107.75 & 10.40 & 44.49 \\
Ear height (cm) & 109.80 & 66.25 & 164.84 & 98.59 & 14.10 & 34.89 \\
Plant aspect & 4.75 & 2.50 & 6.50 & 4.00 & 19.41 & 1.30 \\
Root lodging (\%) & 1.88 & 0.00 & 6.50 & 6.50 & 99.38 & 2.60 \\
Stalk lodging (\%) & 4.86 & 0.00 & 10.50 & 10.50 & 55.42 & 3.70 \\
Husk cover & 3.09 & 2.00 & 4.25 & 2.25 & 19.00 & 1.18 \\
Plants at harvest & 13.41 & 9.75 & 16.13 & 6.38 & 19.40 & 5.10 \\
Field weight of ears (kg) & 1.12 & 0.48 & 2.53 & 2.05 & 31.00 & 0.78 \\
Ears harvested & 9.81 & 4.25 & 14.25 & 10.00 & 28.90 & 5.49 \\
Ear aspect & 4.85 & 2.75 & 7.00 & 4.25 & 16.40 & 1.10 \\
Grain moisture (\%) & 23.06 & 12.29 & 29.88 & 17.59 & 22.40 & 10.19 \\
Grain yield (ton/ha) & 1.63 & 0.62 & 3.67 & 3.05 & 31.20 & 0.98
\end{tabular}

CV: coefficient of variability; $\mathrm{LSD}_{(0.05)}=$ least significant difference at $5 \%$ probability level.

Table 6 Plant characteristics, their ranks and rank summation index of the 212 maize genotypes evaluated under artificially infested, naturally infested and non-infested field conditions.

\begin{tabular}{|c|c|c|c|c|c|c|c|c|c|c|}
\hline \multirow{2}{*}{ Genotype } & \multicolumn{4}{|c|}{ Artificially infested } & \multicolumn{3}{|c|}{ Naturally infested } & \multicolumn{2}{|c|}{ Non-infested } & \multirow{2}{*}{-RSI } \\
\hline & $\begin{array}{l}\text { Ear } \\
\text { damage }\end{array}$ & $\begin{array}{l}\text { Stalk } \\
\text { lodging }\end{array}$ & $\begin{array}{l}\text { Leaf } \\
\text { damage }\end{array}$ & $\begin{array}{l}\text { Yield } \\
\text { (ton/ha ) }\end{array}$ & $\begin{array}{l}\text { Ear } \\
\text { damage }\end{array}$ & $\begin{array}{l}\text { Leaf } \\
\text { damage }\end{array}$ & $\begin{array}{l}\text { Yield } \\
\text { (ton/ha) }\end{array}$ & $\begin{array}{l}\text { Ear } \\
\text { damage }\end{array}$ & $\begin{array}{l}\text { Yield } \\
\text { (ton/ha) }\end{array}$ & \\
\hline $\begin{array}{l}\text { AMA } \\
\text { TZBR-WC }_{1}\end{array}$ & $3(2)$ & $2(33)$ & $3(18)$ & $1.61(4)$ & $2.00(1)$ & $2.00(7)$ & $1.64(2)$ & $3.00(11)$ & $1.97(13)$ & 91 \\
\hline SE NG-77 & $3(2)$ & $1(10)$ & $3(18)$ & $0.92(41)$ & $2.50(12)$ & $2.00(7)$ & $1.46(8)$ & $3.00(11)$ & $1.96(15)$ & 124 \\
\hline SE NG-67 & $3(2)$ & $0(1)$ & $3(18)$ & $0.80(56)$ & $2.00(1)$ & $2.00(7)$ & $1.16(33)$ & $3.00(11)$ & $2.17(9)$ & 138 \\
\hline SE NG-62 & $3(2)$ & $0(1)$ & $3(18)$ & $1.11(23)$ & $2.00(1)$ & $2.50(112)$ & $1.30(16)$ & $2.50(3)$ & $2.58(4)$ & 180 \\
\hline SE NG-148 & $3(2)$ & $3(57)$ & $3(18)$ & $1.12(22)$ & $3.00(38)$ & $2.00(7)$ & $1.34(10)$ & $2.75(6)$ & $1.51(33)$ & 193 \\
\hline SE NG-106 & $3(2)$ & $5(116)$ & $3(18)$ & $1.20(17)$ & $2.50(12)$ & $2.00(7)$ & $1.32(14)$ & $2.75(6)$ & $2.30(6)$ & 198 \\
\hline SE NG-119 & $2(1)$ & $1(10)$ & $4(136)$ & $1.42(9)$ & 3.00 (38) & $2.00(7)$ & $1.49(6)$ & $2.25(1)$ & $2.74(3)$ & 211 \\
\hline SE NG-33 & $4(26)$ & $1(10)$ & $3(18)$ & $1.25(15)$ & 3.50 (93) & $1.50(1)$ & $1.56(4)$ & $3.25(21)$ & $1.65(23)$ & 211 \\
\hline SE NG-65 & $4(26)$ & $1(10)$ & $3(18)$ & $1.41(10)$ & $2.50(12)$ & $2.00(7)$ & $0.99(73)$ & 3.75 (47) & $1.60(26)$ & 229 \\
\hline TZSR-W-1 & $3(2)$ & $2(33)$ & $3(18)$ & $1.20(18)$ & $2.50(12)$ & 2.50 (112) & $1.20(28)$ & $3.00(11)$ & 1.90 (17) & 251 \\
\hline TZBR ELD C $_{2}$ & $3(2)$ & $1(10)$ & $3(18)$ & 0.56 (109) & $2.00(1)$ & $2.50(112)$ & $1.59(3)$ & $2.50(3)$ & $2.01(12)$ & 270 \\
\hline
\end{tabular}

RSI = rank summation index.

to withstand rain storm. Similarly, percentage of the plants which lodged below the ear (stalk lodging) was average of $4.9 \%$, ranging from $0 \%$ to $10.5 \%$. Husk cover ratings for the genotypes averaged 3.1 with a range of 2.0-4.3, indicating that the ears were in most cases tightly covered. With respect to number of plants at harvest, 13 plants per plot survived up to harvest. Mean field weight of the ears harvested per plot was $1.1 \mathrm{~kg}$, ranging from $0.48 \mathrm{~kg}$ to $2.53 \mathrm{~kg}$. Ear aspect rating was moderate (4.8) with a range of 2.8-7.0. Grain moisture content obtained at harvest was $23.06 \%$, ranging from $12.29 \%$ to $29.88 \%$, implying that some genotypes were matured early. Grain yield had a mean of 1.6 ton/ha with a range of 
0.6-3.7 ton/ha. Most of the top yielders were improved checks from IITA, Ibadan, and a few locally collected genotypes were from Southeastern Nigeria. The coefficients of variation - a measure of the relative levels of variability for traits obtained in this study showed high values above $15 \%$ in almost all cases. Root lodging and dead heart had exceptionally high coefficient of variability value of $99.4 \%$ and $80.0 \%$ respectively. However, the coefficient of variation (CV) values for other traits were low ranging from $3.8 \%$ for $50 \%$ silking to $14.1 \%$ for ear height. CV (\%) is a measure of the reliability of the data obtained. Nonetheless, high CVs are common in areas, where results obtained are variable due to inherent variability in infestation, sites and other factors of the environment resulting in non-uniformity of genotypes. Highly significant genotypic variance in all the traits is indicative of the magnitude of variation that exists among the genotypes, thus providing the opportunity for selection. These observations corroborate the reports of earlier workers [16-21], who stated that challenged environments can create a repository of useful genes for crop improvement. Also, farmers' saved seeds from previous cropping represent a form of mass selection, thus such materials may be carrying specific adaptive genetic factors which enable them to survive in such environments.

Rankings of the 212 open-pollinated maize genotypes (Table 6) for stem borer resistance, using ear damage rating, stalk lodging, leaf feeding and grain yield to evaluate the major characteristics necessary for the optimum performance of any acceptable variety in the rainforest agro-ecology of Southeastern Nigeria, showed that genotype AMA TZBR-WC $_{1}$ (from IITA, Ibadan) had the best overall resistance levels with an RSI value of 91, followed by genotypes SE NG-77 and SE NG-67 (from Umuahia North), SE NG-62 (from Ikwuano), SE NG-148 (from Ukwa West), SE NG-106 (from Bende), SE NG-119 (from Isiala Ngwa), SE NG-33 (from Ikwuano) and SE NG-65 (from Umuahia North). In that order, genotype SE NG-32 (from Ikwuano) was the worst with an RSI value of 1441.

\section{Conclusions}

Highly significant genotypic variances and the coefficient of variation values as were noted in all the traits are indicative of the magnitude of variation that exists among the genotypes, thus providing the opportunity of selection for desirable traits. The $G \times E$ interactions obtained in this study indicate that certain genotypes performed comparatively better in some specific environments, thus suggesting the specific adaptive nature of the local genotypes evaluated. Ranking of the genotypes leads to the identification of 11 genotypes, representing top $5 \%$ of the total in resistance ability. Genotype AMA TZBR-WC 1 (from IITA, Ibadan) had the best overall resistance levels, followed by genotypes SE NG-77 and SE NG-67 (from Umuahia North), SE NG-62 (from Ikwuano), SE NG-148 (from Ukwa West), SE NG-106 (from Bende), SE NG-119 (from Isiala Ngwa), SE NG-33 (from Ikwuano) and SE NG-65 (from Umuahia North).

Consequently, developing maize genotypes for the Southeastern region of Nigeria will get necessary benefit from two aspects: (1) improve the locally adapted varieties according to the desirable traits and (2) generate a broadly and widely adapted population, from which experimental varieties can be produced and possibly used in any other environment.

\section{Acknowledgments}

The financial contribution of Dr. Abebe Menkir of IITA, Ibadan and the invaluable lectures of Prof. M. A. B. Fakorede of Obafemi Awolowo University Ile Ife, Nigeria are highly appreciated.

\section{References}

[1] SAFGRAD. 1997. "Maize in Central and Western Africa." In Proceeding of the Workshop on the Establishment of Semi-Arid Food Grain Research and Development (SAFGRAD) Research Network, 321.

[2] Fajemisin, J. E., Efron, Y., Kim, S. K., Khadr, E. H., 
Dabrowski, Z. T., Mareck, J. H., Bjarnsoon, M., Parkinson, V., Everett, L. A., and Diallo, A. 1985. "Population and Varietal Development in Maize for Tropical Africa through Resistance Breeding Approach.” In Breeding Strategies for Maize Production Improvement in the Tropics, edited by Brandolini, A., and Salami, F. Firenze, Italy: FAO and Istitut Agronomico Per L’Oltremare, 385-407.

[3] Bosque-Perez, N. A., and Mereck, J. H. 1990. "Distribution and Species Composition of Lepidopterous Maize Borers in Southern Nigeria.” Bulletin of Entomological Research 80 (4): 363-8.

[4] Obi, I. U. 1991. Maize, Its Agronomy, Diseases, Pests and Food Values. Enugu, Nigeria: Optimal Computer Solutions Limited, 206.

[5] Shanower, T. F., Schulthess, F., and Gounou, S. 1991. "Distribution and Abundance of Some Stem and Cob Borers in Benin.” Plant Health Management Research Monograph No. 1, International Institute of Tropical Agriculture, Ibadan, Nigeria. Accessed February 10, 2014. www.iita.org.

[6] Gounou, S., Schulthess, F., Shanower, T., Hammond, W. N. O., Braima, H., Cudjoe, A. R., Adjakloe, R., Antwi, K. K., and Olaleye, I. 1994. "Stem Borer and Ear Borers of Maize in Nigeria.” Plant Health Management Research Monograph No. 4, International Institute of Tropical Agriculture, Ibadan, Nigeria. Accessed February 10, 2014. www.iita.org.

[7] Kling, J. G., and Bosque-Perez, N. A. 1995. "Progress in Screening and Breeding for Resistance to the Maize Stem Borers E. saccharina and S. calamistis.” In Maize Research for Stress Environments, edited by Jewell, D. C., Waddington, S. R., Ransom, J. K., and Pixley, K. V. Mexico: CIMMYT, 182-6.

[8] Kouame, K. L. 1995. "Seasonal Abundance of the Two Maize Stem Borers S. calamistis and E. saccharina and Bionomics of the Sesamia Egg Parasitoid-Telenomus busseolae.” Ph.D. thesis, Simin Frazer University.

[9] Phiri, G. S. N. 1995. "Interaction of the Spotted Stem Borer Chilo partellus (Swinehoe) with Some Alternative Hosts and Its Larval Parasitoid Cotesia sesamiae (Cameron) in Malawi.” Ph.D. thesis, University of Reading.

[10] Cardwell, K. F., Shulthess, F., Ndemah, R., and Ngoko, Z. 1997. "Maize Yield Losses due to Pests and Diseases in Cameroon.” Agri., Ecosyst. and Environ. 65 (1): 33-47.

[11] Schulthess, F., and Ajala, S. O. 1997. "Recent Advances at IITA in the Control of Stem Borers in West and Central Africa." In Strategy for Sustainable Maize Production in West and Central Africa. Cotonou, Benin Republic: IITA, 451.

[12] Usua, E. J. 1968. "Effects of Varying Populations of Busiola fusca Larvae on the Growth and Yield of Maize." J. of Econ. Ent. 61: 375-6.
[13] Harris, K. M. 1962. "Lepidopterous Stem Borers of Cereals in Nigeria.” Bulletin of Economical Research 53 (1): 139-71.

[14] Appert, J. 1970. "Insects Harmful to Maize in Africa and Madagascar.” Madagascar Institute of Agronomic Research 5: 210-9.

[15] Bowden, J. 1976. "Stem Borer Ecology and Strategy for Control." Annals of Applied Biology 84 (1): 107-34.

[16] Omolo, E. O. 1983. "Screening of Local and Exotic Maize Lines for Stem Borer Resistance with Special Reference to Chilo partellus." International Journal of Tropical Insect Science 4: 105-8.

[17] Ampofo, J. K. O., and Saxena, K. N. 1984. "Host Plant Resistance and Its Significance in Pest Management.” In Proceedings of the International Study Workshop at the International Centre of Insect Physiology and Ecology (ICIPE), 246.

[18] Ampofo, J. K. O., Sexena, K. N., Kibuka, J. G., and Nyangiri, E. O. 1986. "Evaluation of Some Maize Genotypes for Resistance to the Stem Borer Chilo partellus (Swinhoe) in Western Kenya.” Maydica 31: 379-89.

[19] International Center of Insect Physiology and Ecology (ICIPE). 1991. Integrated Pest Management of Crop Borers for Resource-Poor Farmers in Africa-Contribution of Plant Resistance to Insect Pests: Achievements and Highlights 1980-1990. International Center of Insect Physiology and Ecology Annual Report, Nairobi, Kenya.

[20] Ajala, S. O., Smith, L. M., and Odulaja, A. 1995. "Potential of Kenyan Local Maize (Zea mays L.) Germplasm as a Source of Resistance to the Spotted Stem Borer Chilo partellus (Swinhoe).” Trop. Agric. (Trinidad) 72 (4): 297-302.

[21] Ngwuta, A. A., Ajala, S. O., Obi, I. U., and Ene-Obong, E. E. 2001. "Potential Sources of Resistance to Maize Stem Borers (S. calamistis (Hampson) and E. saccharina (Walker)) in Local Maize Populations of Southeastern Nigeria.” Afri. Crop Sci. Proc. 5: 23-8.

[22] SAS Institute. 1999. Statistical Analysis System User's Guide. Version 8. Cary, NC: SAS Institute Inc..

[23] Obi, I. U. 2002. Statistical Methods of Detecting Differences between Treatment Means and Research Methodology Issues in Laboratory and Field Experiments, 2nd ed.. Nsukka, Nigeria: AP Express Publishers Limited, 117.

[24] Hallauer, A. R., and Miranda, J. B. 1988. Quantitative Genetics in Maize Breeding, 2nd ed.. Ames: Iowa State University Press, 468.

[25] Mulumba, N. N., and Mock, J. J. 1978. "Improvement of Yield Potential of the Eto Blanco Maize (Zea mays L.) Population by Breeding for Plant Traits.” Egyptian J. Genet. Cytol. 7: 40-51. 